\title{
Ecosystem-scale compensation points of formic and acetic acid in the central Amazon
}

\author{
K. Jardine ${ }^{1}$, A. Yañez Serrano ${ }^{2}$, A. Arneth ${ }^{2,3}$, L. Abrell ${ }^{4,9}$, A. Jardine ${ }^{1}$, P. Artaxo ${ }^{5}$, E. Alves ${ }^{6}$, J. Kesselmeier ${ }^{7}$, \\ T. Taylor ${ }^{8}$, S. Saleska ${ }^{8}$, and T. Huxman ${ }^{1,8}$ \\ ${ }^{1}$ The University of Arizona-Biosphere 2, P.O. Box 8746, Tucson, AZ 85738, USA \\ ${ }^{2}$ Department of Physical Geography and Ecosystems Analysis, Lund University, Sölvegatan 12, 22362 Lund, Sweden \\ ${ }^{3}$ Karlsruhe Institute of Technology, Institute for Meteorology and Climate Research/Atmospheric Environmental Research, \\ Kreuzeckbahnstr. 19, 82467 Garmisch-Partenkirchen, Germany \\ ${ }^{4}$ Department of Chemistry \& Biochemistry, University of Arizona, P.O. Box 210041, 1306 East University Blvd., Tucson, \\ AZ 85721-0041, USA \\ ${ }^{5}$ Instituto de Fisica, Universidade de Sao Paulo, Rua do Matao, Travessa R,187 Sao Paulo SP 05508-900, Brazil \\ ${ }^{6}$ Large Biosphere-Atmosphere Experiment (LBA), Instituto Nacional de Pesquisas da Amazônia, Av. André Araújo, \\ 2936, Aleixo, CEP 69060-001, Manaus, Brazil \\ ${ }^{7}$ Biogeochemistry Department, Max Planck Institute for Chemistry, P.O. Box 3060, 55020 Mainz, Germany \\ ${ }^{8}$ Department of Ecology and Evolutionary Biology, University of Arizona, P.O. Box 210088, BioSciences West 310, \\ Tucson, AZ, 85721, USA \\ ${ }^{9}$ Department of Soil, Water and Environmental Science, University of Arizona, P.O. Box 210038, Tucson, \\ AZ 85721-0038, USA
}

Received: 31 July 2011 - Published in Biogeosciences Discuss.: 14 September 2011

Revised: 2 December 2011 - Accepted: 5 December 2011 - Published: 16 December 2011

\begin{abstract}
Organic acids, central to terrestrial carbon metabolism and atmospheric photochemistry, are ubiquitous in the troposphere in the gas, particle, and aqueous phases. As the dominant organic acids in the atmosphere, formic acid (FA, $\mathrm{HCOOH})$ and acetic acid $\left(\mathrm{AA}, \mathrm{CH}_{3} \mathrm{COOH}\right)$ control precipitation acidity in remote regions and may represent a critical link between the terrestrial carbon and water cycles by acting as key intermediates in plant carbon and energy metabolism and aerosol-cloud-precipitation interactions. However, our understanding of the exchange of these acids between terrestrial ecosystems and the atmosphere is limited by a lack of field observations, the existence of biogenic and anthropogenic primary and secondary sources whose relative importance is unclear, and the fact that vegetation can act as both a source and a sink. Here, we first present data obtained from the tropical rainforest mesocosm at Biosphere 2 which isolates primary vegetation sources. Strong light and temperature dependent emissions enriched in FA relative to AA were simultaneously observed from individual branches (FA/AA $=3.0 \pm 0.7)$ and mesocosm ambient air $(\mathrm{FA} / \mathrm{AA}=1.4 \pm 0.3)$. We also present long-term
\end{abstract}

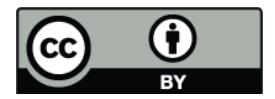

Correspondence to: K. Jardine (jardine@email.arizona.edu) observations of vertical concentration gradients of FA and AA within and above a primary rainforest canopy in the central Amazon during the 2010 dry and 2011 wet seasons. We observed a seasonal switch from net ecosystem-scale deposition during the dry season to net emissions during the wet season. This switch was associated with reduced ambient concentrations in the wet season (FA $<1.3 \mathrm{nmol} \mathrm{mol}^{-1}$, $\mathrm{AA}<2.0 \mathrm{nmol} \mathrm{mol}^{-1}$ ) relative to the dry season (FA up to $3.3 \mathrm{nmol} \mathrm{mol}^{-1}$, AA up to $6.0 \mathrm{nmol} \mathrm{mol}^{-1}$ ), and a simultaneous increase in the FA/AA ambient concentration ratios from $0.3-0.8$ in the dry season to $1.0-2.1$ in the wet season. These observations are consistent with a switch between a biomass burning dominated source in the dry season $(\mathrm{FA} / \mathrm{AA}<1.0)$ to a vegetation dominated source in the wet season $(\mathrm{FA} / \mathrm{AA}>1.0)$. Our observations provide the first ecosystem-scale evidence of bidirectional FA and AA exchange between a forest canopy and the atmosphere controlled by ambient concentrations and ecosystem scale compensation points (estimated to be $1.3 \pm 0.3 \mathrm{nmol} \mathrm{mol}^{-1}$ : FA, and $2.1 \pm 0.4 \mathrm{nmol} \mathrm{mol}^{-1}$ : AA). These results suggest the need for a fundamental change in how future biosphereatmosphere exchange models should treat FA and AA with a focus on factors that influence net exchange rates (ambient concentrations and ecosystem compensation points) rather than treating emissions and deposition separately.

Published by Copernicus Publications on behalf of the European Geosciences Union. 


\section{Introduction}

Short chain organic acids like formic acid (FA, $\mathrm{HCOOH}$ ) and acetic acid (AA, $\mathrm{CH}_{3} \mathrm{COOH}$ ) are ubiquitous in the main biogeochemical reservoirs on Earth including the biosphere, hydrosphere, atmosphere, and geosphere. In the atmosphere, organic acids contribute to the formation and growth of secondary organic aerosols and cloud droplets (Andreae et al., 1988). FA and AA are highly water soluble (low Henry's law constant $<1 \times 10^{-2} \mathrm{~Pa} \mathrm{~m}^{3} \mathrm{~mol}$ ), and therefore partition preferably to the liquid phase (Niinemets and Reichstein, 2003) where they may significantly contribute to the hygroscopicity of cloud condensation nuclei particles and therefore impact precipitation processes (Yu, 2000). While precipitation acidity in polluted areas is often dominated by sulphuric and nitric acid, FA and AA dominate precipitation acidity in remote areas (Kesselmeier and Staudt, 1999; Kesselmeier, 2001; Gabriel et al., 1999). For example, previous studies of rainwater composition in the central Amazon reported little anthropogenic influence in rainwater which was characterized by a low pH (4.7 to 5.3) largely due to the presence of FA and AA (Andreae et al., 1988; Keene et al., 1983; Sanhueza et al., 1991). However, the presence of strong acids like nitric acid in precipitation derived from biomass burning during the dry season may limit the partitioning of weak acids like FA and AA into precipitation. Organic acids may support a surprisingly diverse and metabolically active microbial population in aerosols, cloud droplets, and precipitation. Microorganisms isolated from cloud water can utilize FA and AA as their sole carbon and energy source when cultured in artificial cloud water (Vaitilingom et al., 2010) and ATP concentrations in cloud water fall within the range of expected cell densities for metabolically active cells in clouds (Amato et al., 2007).

FA and AA are the most abundant acids present in both polluted and pristine air masses owing to a relatively long atmospheric lifetime (several days) and a complex array of primary and secondary sources (Paulot et al., 2011). For example, atmospheric mixing ratios in Europe have been reported as high as $11 \mathrm{ppb}$ (for both acids) but typically do not exceed 3 ppb (Kesselmeier, 2001). In the Amazon, ambient concentrations exibited strong seasonal dependencies with much higher concentrations in the dry season (up to $15 \mathrm{nmol} \mathrm{mol}^{-1}$ ) than the wet season (up to $1 \mathrm{nmol} \mathrm{mol}^{-1}$ ) (Kuhn et al., 2002). Although little data exists confirming the identity and magnitude of FA and AA sources, model estimates suggest that secondary production from gas-phase ozonolysis of biogenic precursors like isoprene, and to a lesser extent anthropogenic and biomass burning precursors like acetylene, ethene, and propene dominate global sources (Chebbi and Carlier, 1996; Paulot et al., 2011). Other sources considered important are primary emissions from biomass, biofuel, and fossil fuel burning as well as cattle ranching, soils, and terrestrial vegetation (Paulot et al., 2011).
Under purified air conditions using plant enclosures, vegetation has been clearly shown to emit FA and AA; environmental parameters affecting stomatal opening and/or biosynthesis such as transpiration, photosynthetically active radiation and leaf temperature promoted emissions (Kesselmeier, 2001; Gabriel et al., 1999; Kesselmeier et al., 1998). Within plants, FA is used in the biosynthesis of tetrahydrofolic acid, a key cofactor for one-carbon transfer reactions central to metabolism in all living organisms (Zhang et al., 2010; Christensen and MacKenzie, 2006; Jabrin et al., 2003; Hanson and Roje, 2001; Cossins and Chen, 1997). Although highly uncertain, sources of FA in plants are thought to be related to the oxidation of methanol derived from pectin demethylation (Fall and Benson, 1996) and the oxidation of glyoxylate during photorespiration (Grodzinski, 1979). The production and consumption of AA in plants is tightly linked to the metabolism of the central respiratory/biosynthetic intermediate acetyl-CoA. During the exchange of two carbon units between organelles like mitochondria and chloroplasts, acetyl-CoA hydrolysis produces AA which can be transported and reactivated to acetyl-CoA (Liedvogel and Stumpf, 1982). Recently, a second source of AA in plants has been identified as the pyruvate dehydrogenase bypass where pyruvate is decarboxylated to acetaldehyde which is oxidized to AA (Jardine et al., 2010b).

Although the role of vegetation has been extensively discussed in the atmospheric budget of FA-and AA, it was finally revealed that emissions can be jeopardized by simultaneous consumption within plants which can convert plant leaves from a net atmospheric source to a net sink (Kesselmeier, 2001; Gabriel et al., 1999). This was further demonstrated for individual branches in the Amazon in which ambient FA and AA were effectively removed by tropical plants as a function of the ambient concentrations (Kuhn et al., 2002). Recent observations suggest that the deposition of many oxidized volatile organic compounds from the atmosphere to plant canopies can occur with significantly higher deposition velocities than expected from physicochemical properties like solubility alone (Karl et al., 2010). Active metabolic consumption of oxidized volatile organic compounds (VOCs) by plants can lead to efficient uptake thereby sustaining a large concentration gradient between the atmosphere and the intercellular air spaces; a process that is generally not considered in commonly applied dry deposition schemes. For example in a recent study, atmospheric uptake of low-molecular weight aldehydes and ketones by peace lily (Spathiphyllum clevelandii) and golden pothos (Epipremnum aureum) leaves revealed that the total uptake amounts were 30-100 times as much as the amounts dissolved in the leaf (Tani and Hewitt, 2009). These results suggest that many oxidized VOC can be rapidly metabolized upon entering a leaf.

However, this bidirectional exchange nature of FA and AA between forests and the atmosphere has not yet been clearly demonstrated at the ecosystem scale as it is still not clear if forests act as a net source or a net sink for these 
compounds. In particular, with only a handful of field observations of short durations ( $<1$ month), utilizing offline analytical equipment (often in a laboratory far from the field site), a detailed understanding of FA and AA exchange dynamics between the Amazon forest and the atmosphere is lacking. To date, only a limited number of studies have reported on ambient concentrations of FA and AA in forested ecosystems (Sanhueza et al., 1992; Harrington et al., 1993; Talbot et al., 1990; Talbot et al., 1995; Andreae et al., 1988; Karl et al., 2004; Talbot et al., 1988). To our knowledge, only three of these studies have examined the relative importance of ecosystem-scale emissions versus deposition by quantifying vertical concentration gradients within and above the canopy. In the central Amazon during the dry season, both emission and deposition of FA and AA were observed depending on the time of day (Andreae et al., 1988). It was concluded that a vegetation source and secondary production in the atmosphere were important as well as dry deposition. However, due to the limited dataset, the authors did not determine if the rainforest was a net source or sink of the acids. In the wet season, concentrations within the canopy could not be distinguished between above the canopy but emissions from vegetation were considered significant (Talbot et al., 1990). More recently in a study during the wet to dry season and the dry to wet season transitions in the southwestern Amazon, net ecosystem scale uptake of FA and AA was implied from the higher ambient concentrations above the canopy (Kuhn et al., 2002). This is consistent with results during the dry season in a tropical rainforest in Costa Rica where net deposition of both FA and AA was observed (Karl et al., 2004). Therefore, while vegetation is known to produce FA and AA, a review of the literature tends to conclude that plant canopies mainly act as a net sink. In addition, in all studies deposition appeared to dominate exchange with the soil as the lowest concentrations were always measured near the ground.

In this study, we present the first ecosystem-scale compensation point estimates for FA and AA using long term vertical gradient measurements during the 2010 dry season and 2011 wet seasons in the central Amazon. We also characterize the biogenic FA/AA emission ratio expected in the Amazon Basin by analyzing FA/AA ratios from individual tropical plants and ambient air from the whole tropical rainforest mesocosm at Biosphere 2. We perform a similar analysis of ambient FA/AA ratios in both the central and southwestern Amazon to gain insights into the possible atmospheric sources of FA and AA in both dry and wet seasons.

\section{Experimental}

\subsection{Proton transfer reaction-mass spectrometry (PTR-MS)}

Ambient concentrations of FA and AA were quantified using a commercial high sensitivity proton transfer reaction-mass spectrometer (PTR-MS, IONICON, Austria). The PTR-MS was operated under standard conditions with a drift tube voltage of $600 \mathrm{~V}$ and drift tube pressure of $2.0 \mathrm{mb}(200 \mathrm{~Pa})$. Optimization of PTR-MS conditions resulted in extremely high and sustained primary ion intensities $\left(20-40 \mathrm{MHz} \mathrm{H}_{3} \mathrm{O}^{+}\right.$) with low water cluster $\left(\mathrm{H}_{2} \mathrm{O}-\mathrm{H}_{3} \mathrm{O}^{+}<4 \% \mathrm{H}_{3} \mathrm{O}^{+}\right)$and $\mathrm{O}_{2}^{+}$ $\left(\mathrm{O}_{2}^{+}<4 \% \mathrm{H}_{3} \mathrm{O}^{+}\right)$formation. The following mass to charge ratios $(\mathrm{m} / \mathrm{z})$ were sequentially monitored during each PTRMS measurement cycle; $21\left(\mathrm{H}_{3}^{18} \mathrm{O}^{+}\right), 32\left(\mathrm{O}_{2}^{+}\right), 37\left(\mathrm{H}_{2} \mathrm{O}-\right.$ $\left.\mathrm{H}_{3} \mathrm{O}^{+}\right)$with a dwell time of $20 \mathrm{~ms}$ each and $47\left(\mathrm{FA}-\mathrm{H}^{+}\right)$ and $61\left(\mathrm{AA}-\mathrm{H}^{+}\right)$with a dwell time of $5 \mathrm{~s}$ each. The collisional energy in the drift tube of the PTR-MS instrument was high enough ( $\mathrm{E} / \mathrm{N}$ value of $\sim 136 \mathrm{Td}$ ) to fragment a significant fraction of ethanol $\left(\mathrm{m} / \mathrm{z}^{+}\right)$into $\mathrm{m} / \mathrm{z} 19^{+}$and reduce interference with FA detection. Simultaneous calibrations of both FA and ethanol (see below) revealed 45-67 times greater sensitivities to FA than to ethanol at the $\mathrm{m} / \mathrm{z}$ 47 signal [2.1-2.5 cps/(nmol mol $\left.{ }^{-1}\right)$ for ethanol versus $114-$ $146 \mathrm{cps} /\left(\mathrm{nmol} \mathrm{mol}^{-1}\right)$ for FA]. In addition, other interferences at $\mathrm{m} / \mathrm{z} 61$ expected in tropical rainforest air such as photochemically produced glycolaldehyde were assumed to be $<10 \%$ as discussed previously (Karl et al., 2004). We therefore mainly attribute the PTR-MS signals at m/z 47 and $\mathrm{m} / \mathrm{z} 61$ to FA and AA respectively, in the central Amazon and the Biosphere 2 rainforest mesocosm. This assumption is supported by previous observations of FA and AA in the central Amazon using the technique of ion exchange chromatography (Andreae et al., 1988) where the range of ambient concentrations in the 1985 dry season were 0.5$3.0 \mathrm{nmol} \mathrm{mol}^{-1}$ (FA) and $1.0-5.0 \mathrm{nmol} \mathrm{mol}^{-1}$ (AA). This compares favorably to the range observed in central Amazonia in the 2010 dry season using PTR-MS in the present study of $0.8-3.4 \mathrm{nmol} \mathrm{mol}^{-1}$ (FA) and $1.5-6.0 \mathrm{nmol} \mathrm{mol}^{-1}$ (AA).

While adsorptive losses to surfaces during sampling are potentially a major issue for quantifying organic acids in air samples, gas sampling line losses were minimized by regulating their temperature at $50{ }^{\circ} \mathrm{C}$ using self-regulating heating tape (Omega Engineering) in an insulated jacket. Raw signals (counts per second, cps) were normalized by the adjusted primary ion signal $\left(\mathrm{cps}_{21}\right)$ and background subtracted from measurements of ultra high purity nitrogen (Brazil) or zero air (Biosphere 2) to obtain normalized counts per second (ncps, Eq. 1). In Brazil, a Teflon tee connected to the PTR-MS was overblown with $500 \mathrm{sccm}$ of ultra high purity nitrogen after passing through a hydrocarbon trap (Restek). In Biosphere 2, a Teflon tee connected to the PTR-MS was overblown with $500 \mathrm{sccm}$ of ultra high purity 
zero air (produced using an AADCO 737-series Pure Air Generator with a catalytic converter). The adjusted primary ion signal ( $\left.\mathrm{cps}_{21}\right)$ was obtained by measuring the signal at $\mathrm{m} / \mathrm{z} 21\left(\mathrm{H}_{3}^{18} \mathrm{O}^{+}\right)$and multiplying it by the oxygen isotopic ratio of a representative natural abundance water sample $\left({ }^{16} \mathrm{O} /{ }^{18} \mathrm{O}=500\right)$.

ncps $=\left(\mathrm{cps}_{\mathrm{cps}} \mathrm{cp}_{21}\right)_{\mathrm{sample}}-\left(\mathrm{cps} / \mathrm{cps}_{21}\right)_{\text {background }}$

Calibration slopes $\left(\mathrm{nmol} \mathrm{mol}^{-1} \mathrm{ncps}^{-1}\right)$ for $\mathrm{FA}, \mathrm{AA}$, and ethanol were obtained at Biosphere 2 and twice in the field (Brazil) using the dynamic solution injection (DSI) technique (Jardine et al., 2010a). Solutions were prepared by diluting $5 \mu \mathrm{L}$ of an authentic standard (99\%, Sigma-Aldrich) in $100 \mathrm{~mL}$ of cyclohexane. The solution was injected into the mixing vial at $0.5,1.0,2.0$, and $3.0 \mu \mathrm{L} / \mathrm{min}$ (30 min each flow rate) with a constant dilution flow of 1.0 slpm ultra high purity nitrogen. Sample air AA and FA concentrations were calculated by multiplying the calibration slope by ncps.

\subsection{Biosphere 2 tropical rainforest mesocosm}

The $27000 \mathrm{~m}^{3}$ tropical rainforest mesocosm at Biosphere 2 currently includes 91 species of tropical plants from 41 families, including 73 trees, under a flat-topped pyramidal glass enclosure operated as an open-flow system (Pegoraro et al., 2005). Typical of neotropical forests, the trees are dominated by Fabaceae (pea family) and Arecaceae (palm family). Although not quantified, the mesocosm ventilation rate was controlled by a large vent at the top of the mesocosm which was opened during the day and closed at night to help regulate air temperature. This is qualitatively similar to the vertical mixing pattern in a natural forest where transport of materials and energy out of the canopy is much larger during the day, due to increased vertical mixing, than during the night. Branch enclosure air temperature and ambient air temperature along a vertical profile tower were continuously recorded. Eight 7-10 day measurement periods were made during 22 January-14 April 2010. The eight following species were analyzed for FA and AA emissions using branch enclosures in parallel with ambient air concentration measurements; Mangifera indica L., Pterocarpus indicus Willd., Alpinia zerumbet (Pers.) B. L. Burtt \& R. M. Sm., Hibiscus rosa-sinensis L., Inga vera Willd., Cissus verticillata (L.) Nicolson \& C. E. Jarvis, Canna indica L., and Spathodea campanulata P. Beauv.

Three different air samples from the rainforest mesocosm were continuously pumped at $\sim 1$ slpm through heated $\left(50^{\circ} \mathrm{C}\right)$ Teflon tubing (PFA, $1 / 4$ in. O.D. $\times 60 \mathrm{~m}$ ) into the adjacent laboratory for trace gas analysis and include zero air entering a single $5 \mathrm{~L}$ Teflon branch enclosure, branch enclosure air, and ambient mesocosm air at mid height (13 m). These gas samples as well as zero air inside the laboratory were sequentially analyzed for FA and AA concentrations by PTR-MS (each gas sample measured every hour).

\subsection{BrazilianAir 2010 field campaign}

The BrazilianAir 2010 study was carried out at the TT34 tower $\left(2^{\circ} 35.37^{\prime} \mathrm{S}, 60^{\circ} 06.92^{\prime} \mathrm{W}\right)$ in the Reserva Biologica do Cueiras in central Amazonia, $60 \mathrm{~km}$ NNW of the city of Manaus, Brazil. The site is run by INPA (Instituto Nacional de Pesquisas da Amazonia) under the Large Scale Biosphere-Atmosphere Experiment in Amazonia (LBA) program (Martin et al., 2010). The vegetation in this area is considered to be undisturbed, mature, terra firme rainforest, with a leaf area index of 5-6 and an average canopy height of $30 \mathrm{~m}$ (Karl et al., 2009). The dry season extends from June to September when rainfall is less than $150 \mathrm{~mm}$ per month (October is considered a transition period) and the wet season from November to April when rainfall is greater than $150 \mathrm{~mm}$ per month (May is considered a transition period) (Araujo et al., 2002). However, the 2010 dry season was extended due a large scale drought that affected an estimated $57 \%$ of the Amazon Basin (Lewis et al., 2011) including the central Amazon where rainfall did not climb above $150 \mathrm{~mm}$ per month until December (rainfall measured at the nearby K34 tower, $\sim 2 \mathrm{~km}$ from TT34 tower). Therefore, the dry season measurements described in this manuscript occurred between 2 September 2010 and 5 December 2010 and the wet season measurements occurred between 6 December 2010 and 7 January 2011.

The FA and AA gradient measurement scheme employed was based on that used in the AMAZE 2008 campaign (Karl et al., 2009) with six ambient air inlets extending throughout and above the $30 \mathrm{~m}$ tall canopy at $2,11,17,24,30$, and $40 \mathrm{~m}$ tower heights. To prevent condensation and minimize FA and AA losses during sampling, all Teflon gas inlets were continuously heated to $\sim 50^{\circ} \mathrm{C}$ using self-regulating heating tape (Omega Engineering) in an insulated jacket. The six inlets were sequentially analyzed for FA and AA concentrations (10 min at each inlet, one complete canopy profile per hour). The air sample tubing lengths were equal to the inlet heights plus an additional $4 \mathrm{~m}$ each to reach the detector in the instrument trailer directly adjacent to the tower. Ambient air was drawn through $1 / 4$ in O.D. Teflon PFA tubing using an oil free diaphragm pump (KNF Neuberger) with a sample point to detector delay time of $<15 \mathrm{~s}$. Prior to each vertical gradient ambient air measurement period (lasting 4-7 days), ultra high purity nitrogen was run for two hours directly into the PTR-MS to obtain instrument background signals. Vertical gradients were calculated by averaging the last seven minutes of each ten minute measurement period. Average vertical gradients during the day (10:00-16:00 LT) were calculated for each measurement period in the dry and wet seasons.

\subsection{Southwestern Amazon}

FA/AA ambient concentration ratios were obtained at a tower within the primary open rainforest of Rebio Jaru nature 
reserve (canopy height $25-45 \mathrm{~m}$ ) and at a scaffold reaching the canopy top (8-14 m) within the Rebio Jaru nature reserve at the camp site of the Brazilian Environmental Protection Agency IBAMA (Instituto Brasileiro de Meio Ambiente e Recursos Renováveis). Sampling heights were 51 $\mathrm{m}$ and $8-10 \mathrm{~m}$, respectively. Both field measurements were performed during the transition from wet to dry season (May 1999) or from dry to wet season (September-October 1999) (Kesselmeier et al., 2002).

\section{Results and discussion}

\subsection{Biosphere 2 tropical rainforest mesocosm}

In this study, dynamic Teflon branch enclosures were used to study diurnal patterns in FA and AA emissions from several tree species within the Biosphere 2 tropical rainforest mescosm. Seven out of the eight tropical species investigated displayed strong diurnal emissions of both FA and AA with maximum emission rates between $0.02-0.08 \mathrm{nmol} \mathrm{m}^{-2} \mathrm{~s}^{-1}$ and $0.01-0.06 \mathrm{nmol} \mathrm{m}^{-2} \mathrm{~s}^{-1}$ for FA and AA, respectively (significant emissions were not detected from a single species, I. vera). This range of emissions rates is consistent with a recent literature survey that found a range of FA emissions from plants of $0.02-0.11 \mathrm{nmol} \mathrm{m}^{-2} \mathrm{~s}^{-1}$ (with a few reports of emissions as high as $\left.0.49-0.86 \mathrm{nmol} \mathrm{m}^{-2} \mathrm{~s}^{-1}\right)$ and AA emissions of $0.01-0.13 \mathrm{nmol} \mathrm{m}^{-2} \mathrm{~s}^{-1}$ (with a few reports of emissions as high as $0.33-0.75 \mathrm{nmol} \mathrm{m}^{-2} \mathrm{~s}^{-1}$ ) (Seco et al., 2007).

Ambient concentrations within the rainforest mesocosm during the three-month study reached maximum daytime values of $2.5-4.1 \mathrm{nmol} \mathrm{mol}^{-1}$ and $1.4-3.3 \mathrm{nmol} \mathrm{mol}^{-1}$ for FA and AA, respectively. These values are within the range of maximum ambient FA and AA concentrations previously observed during the wet $\left(0.5-2.0 \mathrm{nmol} \mathrm{mol}^{-1}\right)$ and dry (4$17 \mathrm{nmol} \mathrm{mol}^{-1}$ ) seasons in the southwestern Amazon (Kuhn et al., 2002; Kesselmeier et al., 2002). As has previously been observed from other plants (Harley et al., 2007; Huve et al., 2007), we observed strong methanol branch emission bursts from several tropical species in the morning following stomatal opening in accord with liquid phase accumulation at night followed by morning release (Figs. S1 and S2, supporting information). In some cases, (e.g. H. rosa-sinensis, Fig. S1), methanol emissions were dominated by the morning burst while in others (e.g. S. campanulata, Fig. S2), large methanol emissions occurred both in the morning and during mid-day when PAR was elevated. In contrast with methanol, FA and AA did not show morning bursts suggesting that they do not accumulate at night, possibly due to rapid consumption by primary metabolism (e.g. AA activation to acetyl-CoA and FA conversion to tetrahydrofolic acid) and/or their sources are strongly light and temperature dependent (e.g. dependent on photosynthesis, glycolysis, photorespiration, etc.).
In general, we found that branch fluxes and ambient concentrations of FA and AA tracked air temperature well (see Fig. 1 and supplementary Figs. S1-6). In order to prevent cold stress at night, air handlers often turned on to warm the air when the ambient temperatures dropped below to $20^{\circ} \mathrm{C}$. In response, FA and AA ambient concentrations slightly increased (see Fig. 1 and supplementary Figs. S1-6). In addition, maximum ambient air temperatures and FA and AA ambient concentrations often occurred $1-2 \mathrm{~h}$ after maximum PAR (see Fig. 1 and supplementary Figs. S1-5). Moreover, because some branch enclosures were located on the west side of the mesocosm which receives sunlight later than the east side, enclosure air temperatures increased in the morning before direct sunlight was received by the branches (Fig. 1, supplementary Fig. S6, S5). In these branches, FA and AA emissions significantly increased with temperature prior to the strong rise in PAR. These observations suggest that denovo biosynthesis and emissions of FA and AA are not completely dependent upon photosynthesis. However, the importance of light is implied from ambient air observations during the winter where ambient air temperatures at night approached those during the day (due to heating at night by the air handlers) yet ambient FA and AA concentrations were greatly stimulated during the day relative to the night (supplementary Fig. S3). In addition, FA and AA emissions from a single species (mango: $M$. indica), appeared to track PAR better than air temperature (supplementary Fig. S3).

Emissions of FA from all seven species correlated linearly with AA emissions (Average: $R^{2}=0.7 \pm 0.1$, Range: $0.6-0.8$ ) and FA/AA branch emission ratios were strongly enhanced in FA relative to AA [FA/AA emission ratio $=3.0 \pm 1.2\left(\mathrm{nmol} \mathrm{m}^{-2} \mathrm{~s}^{-1} \mathrm{FA}\right) /(\mathrm{nmol} \mathrm{m})^{-2} \mathrm{~s}^{-1}$ AA), Range: $\quad 1.5-4.6\left(\mathrm{nmol} \mathrm{m}^{-2} \mathrm{~s}^{-1} \mathrm{FA}\right) /\left(\mathrm{nmol} \mathrm{m}^{-2} \mathrm{~s}^{-1}\right.$ AA)\}. Similar with branch emissions, ambient concentrations of FA correlated linearly with those of AA (Average: $R^{2}$ of $0.89 \pm 0.10$, Range $0.69-0.98$ ) and FA/AA ambient concentration ratios were also enhanced in FA relative to AA \{Average: FA/AA concentration ratio $=1.4 \pm 0.3\left(\mathrm{nmol} \mathrm{mol}^{-1} \mathrm{FA}\right) /\left(\mathrm{nmol} \mathrm{mol}^{-1} \mathrm{AA}\right)$, Range: 1.1-2.0 (nmol mol $\left.\left.{ }^{-1} \mathrm{FA}\right) /\left(\mathrm{nmol} \mathrm{mol}^{-1} \mathrm{AA}\right)\right\}$. These observations provide evidence that FA/AA emission ratios from vegetation are more enriched in FA than AA which can potentially be used as a signature of biogenic sources in the atmosphere. However, because of the use of purified air in the branch enclosures and the semi-closed nature of the rainforest mesocosm, net uptake was prevented. Therefore, these features are useful to isolate the FA/AA emission ratios from tropical vegetation while eliminating secondary photooxidation and other potentially dominant sources in the Amazon like biomass burning. However, the bidirectional exchange nature of ecosystem-atmosphere exchange, as has been observed using ambient air in individual plant enclosures (Bode et al., 1997; Kesselmeier, 2001; Kuhn et al., 2002), requires an analysis of ambient air in a natural forest. 

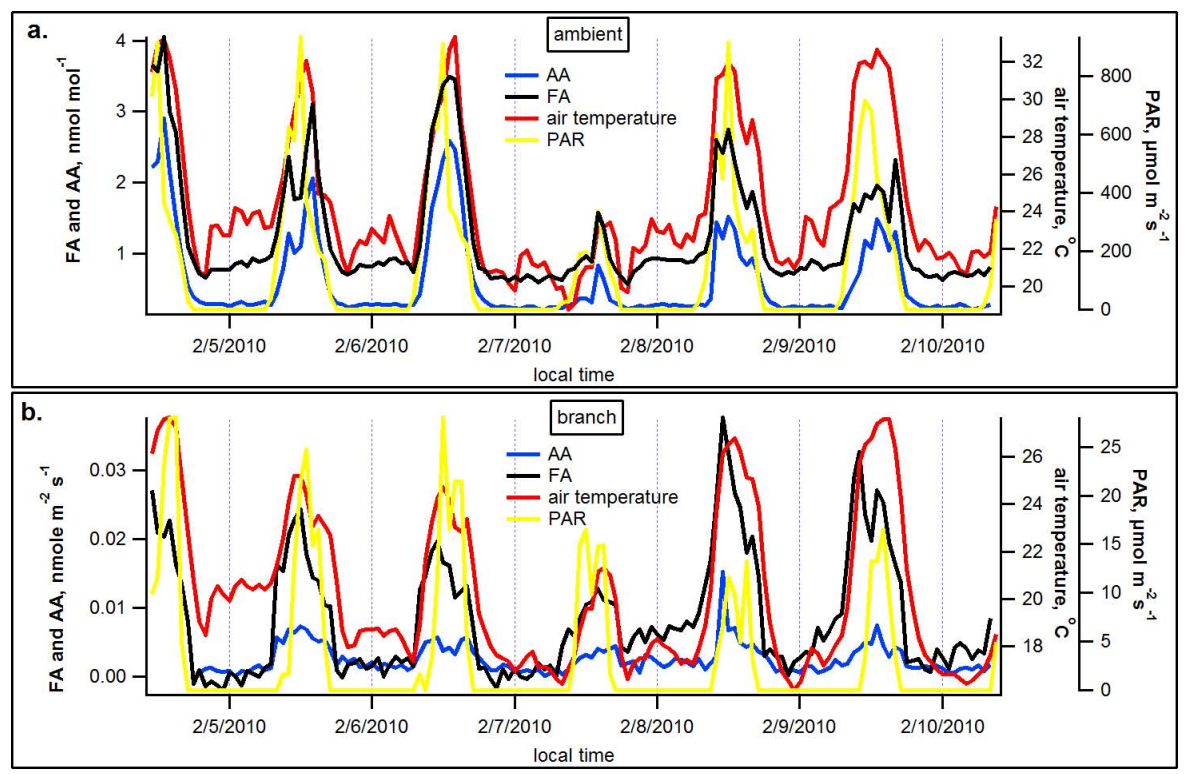

Fig. 1. Example of simultaneous FA and AA time series in the Biosphere 2 tropical rainforest mesocosm (a) ambient concentrations in the mesocosm (16 m height) (b) branch emission rates from an isolated A. zerumbet branch. Temperature and PAR are also shown (ambient conditions at $20 \mathrm{~m}$ height in mesocosm and in the branch enclosure).

\subsection{BrazilianAir 2010}

In order to investigate the role of a primary tropical rainforest in the central Amazon in the biosphere-atmosphere exchange of FA and AA during the dry and wet seasons, we collected continuous in-situ vertical concentration profiles within and above the canopy utilizing high sensitivity online PTR-MS. During the 2010 dry season, weekly averaged vertical gradients of ambient FA and AA generally showed net ecosystem deposition with the highest concentrations above the canopy and declining thereafter within the canopy (Figs. 2a, 3a). In contrast, during the 2011 wet season the highest ambient concentrations were observed at the top of the canopy (30 m) rather than above the canopy ( $40 \mathrm{~m}$ ) (Figs. 2b, 3b). This implies the ecosystem is a net emission source, with highest emissions of FA and AA at the top of the canopy. This is consistent with the studies at Biosphere 2 where emissions of FA and AA increased with PAR and temperature (Fig. 1) which are expected to be the highest at the top of the canopy. In both the wet and the dry seasons, the lowest ambient concentrations observed were near the ground $(2 \mathrm{~m})$ confirming the view that soils/litter in tropical forests can act as effective FA and AA sinks throughout the year assuming sufficient moisture to sustain microbial consumption of organic acids and/or provide a water film to dissolve the acids. With leaf surfaces on average drier in the upper canopy, the increase in surface wetness within the canopy and at the surface likely contributes to FA and AA deposition there.
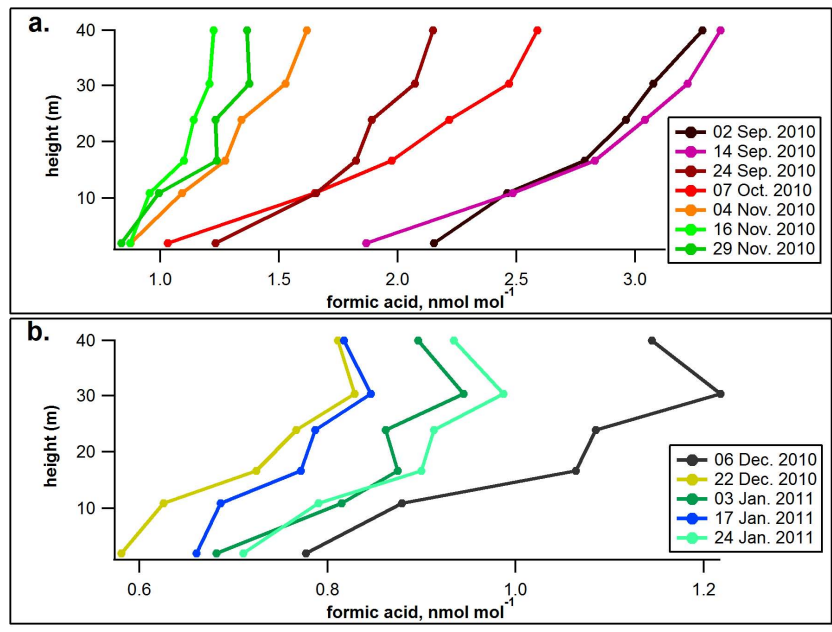

Fig. 2. Weekly averaged vertical concentrations of FA within and above the $30 \mathrm{~m}$ canopy in the central Amazon (start date shown). (a) 2010 dry season with high FA concentrations (0.8$3.3 \mathrm{nmol} \mathrm{mol}^{-1}$ ) and net deposition. (b) 2010-2011 wet season with low concentrations $\left(0.6-1.2 \mathrm{nmol} \mathrm{mol}^{-1}\right)$ and net emissions. The typical standard deviation at each height was about $21 \%$ of the mean FA concentration values.

Although concentrations do not directly resemble exchange fluxes, in absence of fundamental changes in turbulent mixing, these long-term observations suggest that there is a seasonal switch between net deposition of FA and AA during the dry season under elevated ambient concentrations 

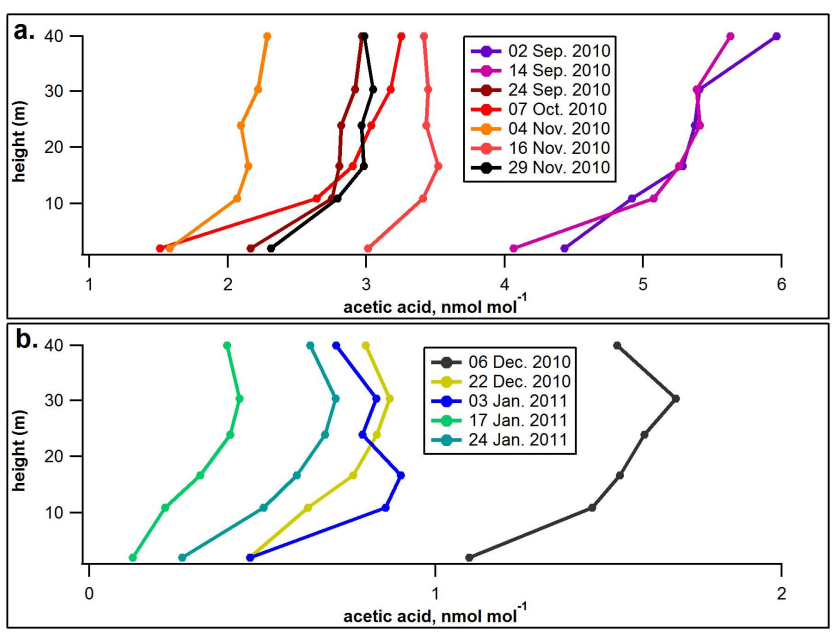

Fig. 3. Weekly averaged vertical concentrations of AA within and above the $30 \mathrm{~m}$ canopy in the central Amazon (start date shown). (a) 2010 dry season with the highest AA concentrations (1.5$6.0 \mathrm{nmol} \mathrm{mol}^{-1}$ ) and net deposition. (b) 2010-2011 wet season with low concentrations $\left(0.1-1.7 \mathrm{nmol} \mathrm{mol}^{-1}\right)$ and net emissions. The typical standard deviation at each height was about $27 \%$ of the mean AA concentration values.

(FA up to $3.3 \mathrm{nmol} \mathrm{mol}^{-1}$, AA up to $6.0 \mathrm{nmol} \mathrm{mol}^{-1}$ ) and net emissions during the wet season under reduced ambient concentrations (FA $<1.3 \mathrm{nmol} \mathrm{mol}^{-1}, \mathrm{AA}<2.0 \mathrm{nmol} \mathrm{mol}^{-1}$ ). This pattern of acting as both a net source and a net sink, depending on the prevailing ambient concentrations of FA and AA has also been demonstrated for individual branches in enclosures (Kesselmeier, 2001). When consumption dominates production as might be expected in shaded environments with low PAR and temperatures, the continuous utilization of FA and AA will maintain the concentration gradient between the atmosphere and within plants; the driving force that allows for continuous stomatal uptake of organic acids. In contrast, if production dominates consumption as might be expected in the high PAR and temperature environments at the top of forest canopies, this uptake can be counterbalanced by plant metabolic production resulting in higher concentrations within plants than the ambient air and net emissions. Based on these processes, the compensation point defines an ambient mixing ratio where consumption and production balance each other and the net flux is zero (Jardine et al., 2008). The organic acid emission rate (the ordinate intercept, $\mathrm{nmol} \mathrm{m}{ }^{-2} \mathrm{~s}^{-1}$ ), the exchange velocity (slope, $\mathrm{m} \mathrm{s}^{-1}$ ) and the compensation point concentration (abscissa intercept, $\mathrm{nmol} \mathrm{m}^{-3}$ ) can be determined by linear regression of observed fluxes versus the ambient concentration, where ambient concentrations above the compensation point leads to net organic acid uptake and vice versa.

To our knowledge, only a single study has reported plant compensation points for FA $\left(0.24-0.30 \mathrm{nmol} \mathrm{mol}^{-1}\right)$ and AA (0.16-0.17 nmol mol ${ }^{-1}$ ) (Kuhn et al., 2002). While the authors were not able to detect net emissions due to the very low compensation points and possibly ambient air contamination from a pump, the ambient uptake fluxes in the branch enclosures were linearly dependent on the ambient concentrations in the enclosure. These very low compensation points determined by Kuhn et al., 2002 may be related to the use of branches within the canopy of the secondary forest measured at a height of 8-10 $\mathrm{m}$ which might be expected to have much lower production rates than the top of the canopy where PAR and temperature are likely much higher. A strong dependence on light/temperature has been shown for compensation points of acetaldehyde which also exhibits bidirectional exchange (Jardine et al., 2008) and Kuhn et al., 2002 suggested that net emissions rather than deposition may have occurred in the upper canopy during the wet season under reduced ambient concentrations. Although ecosystem fluxes were not measured during the BrazilianAir 2010 field campaign, we estimated ecosystem scale compensations points for FA and AA during both the dry and wet season by regressing the ambient concentration difference between the top of the canopy and above the canopy (the assumed driver of net exchange flux) versus the ambient concentration at the top of the canopy for each measurement period (Fig. 4). Canopy emissions are indicated by positive values and deposition by negative values. Similar to what has been observed at the branch scale (Kuhn et al., 2002; Kesselmeier, 2001), we found strong linear dependencies on FA and AA concentration differences and ambient concentrations at the top of the canopy. Using this method, we estimate an ecosystem scale compensation point of $1.3 \pm 0.3 \mathrm{nmol} \mathrm{mol}^{-1}$ and $2.1 \pm 0.4 \mathrm{nmol} \mathrm{mol}^{-1}$ for FA and AA, respectively. While higher than the branch level compensation points made in the Amazon under field conditions, the elevated compensation points estimated for the entire rainforest ecosystem are likely related to higher PAR and temperature conditions at the top of the canopy relative to within the canopy. Furthermore, an ecosystem scale compensation point encloses exchange processes affected by multiple sinks and sources beyond vegetation including dissolving into surface water films within the canopy and at the surface, microbial processes, within canopy gas phase photooxidation of VOCs, and turbulent transport. Nonetheless, our method is limited by the fact that we assume a constant ecosystem compensation point for FA and AA during both the dry and wet seasons despite the higher PAR and temperature conditions during the dry season relative to the wet season. However, even if FA and AA compensation points are elevated in the dry season relative to the wet season, our vertical concentration profiles suggest that the even higher ambient concentrations during the dry season still drive net ecosystem uptake of these compounds. In addition, although reduced ecosystem compensation points in the wet season would tend to support net ecosystem FA and AA uptake, ambient concentrations are even lower which leads to net emissions. Therefore, seasonal changes in ambient concentrations appear to be more important than seasonal 

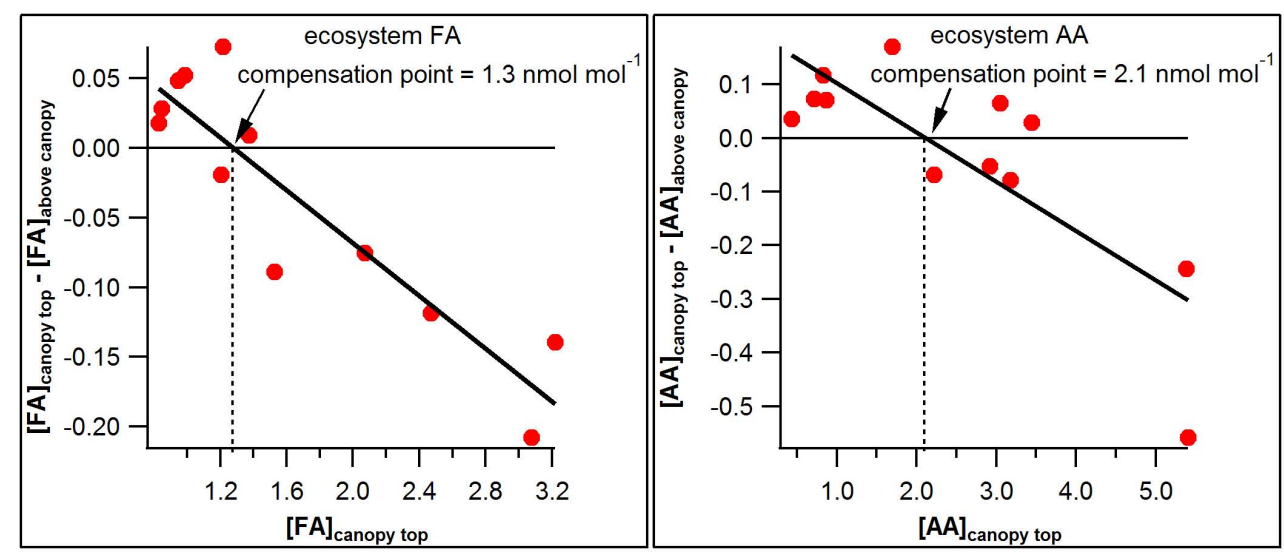

Fig. 4. Ecosystem scale compensation point estimates for FA and AA. The exchange driver, the average concentration difference $\left(\mathrm{nmol} \mathrm{mol}{ }^{-1}\right)$ between the top of the canopy $(30 \mathrm{~m})$ and above the canopy $(40 \mathrm{~m})$ are plotted versus the concentration $\left(\mathrm{nmol} \mathrm{mol}{ }^{-1}\right)$ at the top of the canopy. Canopy emission are indicated by positive values and deposition by negative values and the compensation point is defined as the ambient concentration $\left(\mathrm{nmol} \mathrm{mol}^{-1}\right)$ at the top of the canopy where the concentration difference, and therefore the exchange flux is zero (X-intercept).

changes in ecosystem FA and AA compensation points in determining the net direction of FA and AA exchange fluxes between the primary rainforest and the atmosphere.

In addition, one potentially important control over biosphere-atmosphere exchange of FA and AA that is currently not considered is the role of canopy conductance which may have a seasonal pattern in the Amazon (Vourlitis et al., 2008; Sommer et al., 2002). Unlike isoprene whose emission rates have been shown to be insensitive to changes in stomatal conductance due to the counterbalancing effect of isoprene buildup in the intercellular air spaces following stomatal closure (Fall and Monson, 1992), physicochemical simulations suggest that stomatal behavior may influence FA and AA exchange rates (Niinemets and Reichstein, 2003). Due to the high water solubility of these compounds, gas-phase concentrations within plants do not significantly increase upon decreased stomatal conductance due to their preferential partitioning into the aqueous phase. However, this model does not include biological consumption within plants which may limit the potential for large pools of FA and AA to accumulate in plants upon stomatal closure. However, as has been experimentally demonstrated for acetaldehyde (Jardine et al., 2008), stomatal conductance may only influence the FA and AA exchange velocities (slope of flux versus concentration curve) and not the compensation points (x-intercept of flux versus concentration curve) which are primarily determined by the relative rates of biochemical production and consumption processes. Nonetheless, the lack of available experimental data on the relationship between stomatal conductance and FA and AA exchange rates and compensation points, these ideas remain speculative. This highlights the need for a focused study on the plant physiological and environmental factors that influence the bidirectional exchange of FA and AA between plants and the atmosphere.

The switch of the primary rainforest ecosystem from a net sink during the dry season under elevated ambient concentrations to a net source during the wet season under reduced ambient conditions deserves additional analysis. What is/are the major atmospheric source(s) of FA and AA during the dry season that results in elevated ambient concentrations and consequently, net ecosystem uptake? To gain additional insight into the potential sources, we calculated ambient FA/AA ratios above the canopy for each measurement period in both the dry and wet seasons (Fig. 5). We found that associated with the dry to wet season transition in December 2010, ambient FA/AA ratios increased from less than 1 to greater than 1 . Moreover, the FA/AA ratios in the dry season were within the range of that determined for biomass burning plumes which were depleted in FA (Goode et al., 2000), while the wet season values were enriched in FA and in the range of values determined for biogenic emissions at Biosphere 2. Therefore, we hypothesize that the seasonal variability in FA/AA ratios in ambient air is due to a shift in the relative dominance of biomass burning (dry season) and biogenic (wet season) sources; an idea supported by legacy data from the southwestern Amazon (Kesselmeier et al., 2002) where a shift was observed from FA/AA ratios $\sim 1.0$ in the dry season to values greater than 1.0 in the wet season (Fig. 6). A similar proposed seasonal switch between biomass/fossil fuel dominated tropospheric sources of FA and AA during the winter $(\mathrm{FA} / \mathrm{AA}<1)$ and vegetation dominated source during the summer (FA/AA $>1$ ) has also been described in Virginia, USA (Talbot et al., 1988).

Because secondary production of FA and AA from biogenic and anthropogenic precursors are enriched in FA 


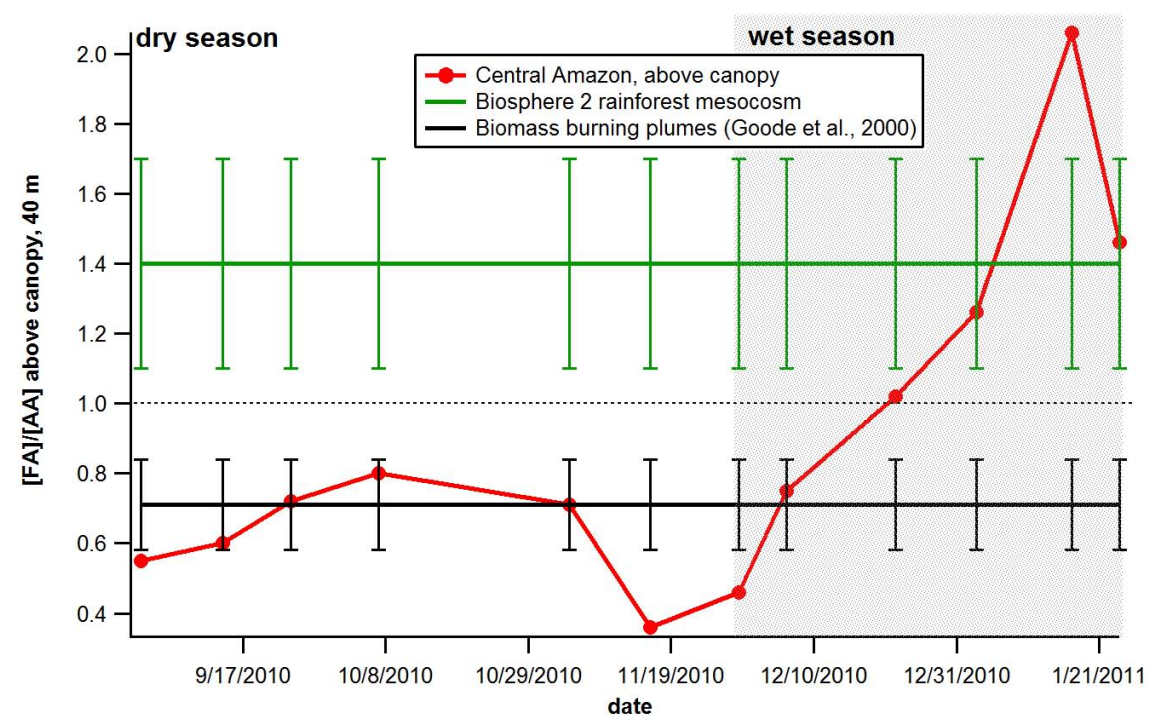

Fig. 5. Time series of FA/AA concentration ratios above the canopy in central Amazonia ( $40 \mathrm{~m}$ ) through the 2010 dry and 2011 wet seasons showing a potential switch between a biomass burning dominated source in the dry season to a vegetation dominated source in the wet season. For comparison, average FA/AA ratios observed in the Biosphere 2 tropical rainforest mesocosm measured in this study and from biomass burning plumes in Goode et al., 2000 are also shown (error bars represent one standard deviation).

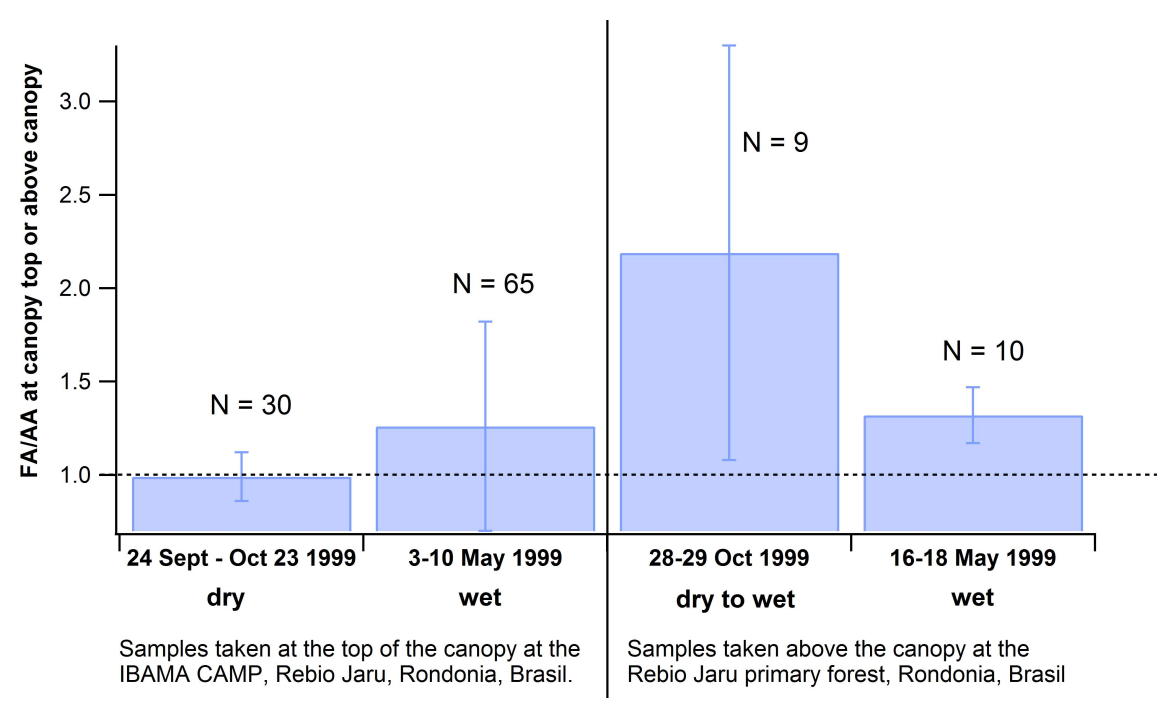

Fig. 6. Daytime (10:00-16:00 LT) ratios of FA to AA $\left(\mathrm{nmol} \mathrm{mol}^{-1} \mathrm{FA}\right) /\left(\mathrm{nmol} \mathrm{mol}^{-1} \mathrm{AA}\right)$ in the southwestern Amazon during the 1999 dry and wet seasons and the transition from dry to wet. Wet season data at canopy top tended to slightly higher ambient ratios (FA/AA $>1$ ) as compared to the dry season data $(\mathrm{FA} / \mathrm{AA}=1)$. The late dry season data at the tower show the opposite with higher values than in the wet season. However, after a drought from June to August, quite substantial rainfall was observed very early in the dry-to-wet season transition in September triggering re-greening of the forest (Kesselmeier et al., 2002).

relative to AA (FA/AA > 1) (Grosjean, 1992), our data do not support a dominant role of secondary production in elevating the ambient dry season concentrations. A recent global modeling paper concluded that secondary production from the ozonolysis of biogenic precursors like isoprene is by far the dominant atmospheric source (Paulot et al., 2011). However, a study in Shenandoah National Park in Virginia,
USA concluded that the secondary ozonolysis of biogenic precursors like isoprene do not exert a large influence on ambient FA and AA concentrations (Talbot et al., 1995). However, as the single largest source of isoprene to the global atmosphere (Guenther et al., 2006) with rapid photochemistry (Karl et al., 2009), these studies highlight the need for a better understanding of the atmospheric budgets of FA and 
AA in the Amazon Basin and the importance of primary and secondary biogenic and anthropogenic sources on atmospheric composition. Our analysis suggests that in the central Amazon basin, biomass burning dominates atmospheric concentrations during the dry season. This conclusion was also reached by several other measurement and modeling studies in the southwestern Amazon (Kesselmeier et al., 2002; Andreae and Merlet, 2001) where biomass burning is extremely prevalent as a part of the "arc of deforestation" (Fearnside et al., 2009).

\section{Summary and conclusions}

As key intermediates in a number of metabolic processes, there is a growing consensus that a large number of oxygenated compounds are both produced and consumed by plants and that bidirectional exchange occurs between tropical forests and the atmosphere (Ganzeveld et al., 2008; Jardine et al., 2008; Karl et al., 2005). In a recent study that focused on methanol and acetone (Ganzeveld et al., 2008), it was found that a commonly applied algorithm to simulate global acetone and methanol biogenic exchanges substantially overestimates ambient concentrations and emission strengths (compared with observations). In contrast, the use of a compensation point approach simulated ambient concentrations and exchange dynamics that were much more comparable to observations. It was concluded that the currently applied algorithm to simulate global acetone and methanol biogenic exchanges appears to substantially overestimate the tropical forest source strengths. Therefore, in order to accurately simulate biosphere-atmosphere fluxes and atmospheric concentrations of oxygenated VOCs in Earth System Models, a modeling approach that embraces the bidirectional exchange nature of oxygenated VOCs (e.g., a compensation point approach) is needed.

In this study, we present results of in situ, high vertically resolved ambient concentration measurements of FA and AA within and above a primary rainforest canopy in the central Amazon during both the 2010 dry and 2011 wet seasons. We show that a switch occurs between net deposition during the dry season under elevated ambient concentrations and net emissions during the wet season under reduced ambient concentrations. In addition to the first clear study showing that plant canopies can be a net source of FA and AA to the atmosphere, as has been demonstrated at the branch scale (Kesselmeier, 2001; Kuhn et al., 2002), our observations are also the first ecosystem-scale evidence that biosphere-atmosphere exchange of FA and AA are determined by ambient concentrations and an ecosystem scale compensation point. This demonstrates that the interaction of climate and anthropogenic activities like biomass burning exert a fundamental control over the net exchange direction of FA and AA in the Amazon by altering the strength and relative contributions of anthropogenic versus biogenic sources.
The terrestrial biosphere may therefore be viewed as a buffer of atmospheric FA and AA concentrations by acting as a sink when concentrations increase above the ecosystem compensation point and a source when they decline below it.

\section{Supplementary material related to this article is available online at: http://www.biogeosciences.net/8/3709/2011/ bg-8-3709-2011-supplement.pdf.}

Acknowledgements. Funding for this project was provided by the Philecology Foundation of Fort Worth, Texas and the National Science Foundation through the AMAZON-PIRE (Partnerships for International Research and Education) award (0730305) and instrumentation support (CHE 0216226). AA and AYS acknowledge support from the Swedish Research Councils VR and Formas. We would like to thank several individuals at the Instituto Nacional de Pesquisas da Amazônia (INPA) in Manaus, Brazil for logistics support including Roberta Pereira de Souza, Françoise Yoko Ishida, Erika Schloemp, and Antonio Manzi.

Edited by: L. Ganzeveld

\section{References}

Amato, P., Parazols, M., Sancelme, M., Mailhot, G., Laj, P., and Delort, A. M.: An important oceanic source of micro-organisms from cloud water at the Puy de Dôme (France), Atmospheric Environment, 41, citeulike-article-id:6775351, 8253-8263, 2007.

Andreae, M. O. and Merlet, P.: Emission of trace gases and aerosols from biomass burning, Global Biogeochem. Cy., 15, 955-966, 2001.

Andreae, M. O., Talbot, R. W., Andreae, T. W., and Harriss, R. C.: Formic and Acetic-Acid over the Central Amazon Region, Brazil 1. Dry Season, J. Geophys. Res.-Atmos., 93, 1616-1624, 1988.

Araujo, A. C., Nobre, A. D., Kruijt, B., Elbers, J. A., Dallarosa, R., Stefani, P., von Randow, C., Manzi, A. O., Culf, A. D., Gash, J. H. C., Valentini, R., and Kabat, P.: Comparative measurements of carbon dioxide fluxes from two nearby towers in a central Amazonian rainforest: The Manaus LBA site, J. Geophys. Res.Atmos., 107, 8090, doi:10.1029/2001JD000676, 2002.

Bode, K., Helas, G., and Kesselmeier, J.: Biogenic contribution to atmospheric organic acids, in: Biogenic Volatile Organic Compounds in the Atmosphere, edited by: Helas, G., Slanina, Steinbrecher R, SPB Academic Publishing, Amsterdam, 1997.

Chebbi, A. and Carlier, P.: Carboxylic acids in the troposphere, occurrence, sources, and sinks: A review, Atmos. Environ., 30, 4233-4249, 1996.

Christensen, K. E. and MacKenzie, R. E.: Mitochondrial one-carbon metabolism is adapted to the specific needs of yeast, plants and mammals, Bioessays, 28, 595-605, doi:10.1002/Bies.20420, 2006.

Cossins, E. A. and Chen, L. F.: Folates and one-carbon metabolism in plants and fungi, Phytochemistry, 45, 437-452, 1997.

Fall, R. and Monson, R. K.: Isoprene Emission Rate and Intercellular Isoprene Concentration as Influenced by Stomatal Distribution and Conductance, Plant Physiology, 100, 987-992, 1992. 
Fall, R. and Benson, A. A.: Leaf methanol - The simplest natural product from plants, Trends Plant Sci, 1, 296-301, 1996.

Fearnside, P. M., Righi, C. A., Graca, P. M. L. D., Cerri, C. C., and Feigl, B. J.: Biomass burning in Brazil's Amazonian "arc of deforestation": Burning efficiency and charcoal formation in a fire after mechanized clearing at Feliz Natal, Mato Grosso, Forest Ecology and Management, 258, 2535-2546, doi:10.1016/j.foreco.2009.09.010, 2009.

Gabriel, R., Schafer, L., Gerlach, C., Rausch, T., and Kesselmeier, J.: Factors controlling the emissions of volatile organic acids from leaves of Quercus ilex L. (Holm oak), Atmos. Environ., 33, 1347-1355, 1999.

Ganzeveld, L., Eerdekens, G., Feig, G., Fischer, H., Harder, H., Königstedt, R., Kubistin, D., Martinez, M., Meixner, F. X., Scheeren, H. A., Sinha, V., Taraborrelli, D., Williams, J., VilàGuerau de Arellano, J., and Lelieveld, J.: Surface and boundary layer exchanges of volatile organic compounds, nitrogen oxides and ozone during the GABRIEL campaign, Atmos. Chem. Phys., 8, 6223-6243, doi:10.5194/acp-8-6223-2008, 2008.

Goode, J. G., Yokelson, R. J., Ward, D. E., Susott, R. A., Babbitt, R. E., Davies, M. A., and Hao, W. M.: Measurements of excess $\mathrm{O}-3, \mathrm{CO} 2, \mathrm{CO}, \mathrm{CH} 4, \mathrm{C} 2 \mathrm{H} 4, \mathrm{C} 2 \mathrm{H} 2, \mathrm{HCN}, \mathrm{NO}, \mathrm{NH} 3$, $\mathrm{HCOOH}, \mathrm{CH} 3 \mathrm{COOH}, \mathrm{HCHO}$, and $\mathrm{CH} 3 \mathrm{OH}$ in 1997 Alaskan biomass burning plumes by airborne fourier transform infrared spectroscopy (AFTIR), J. Geophys. Res.-Atmos., 105, 2214722166, 2000.

Grodzinski, B.: Study of Formate Production and Oxidation in Leaf Peroxisomes during Photo-Respiration, Plant Physiology, 63, 289-293, 1979.

Grosjean, D.: Formic-Acid and Acetic-Acid - Emissions, Atmospheric Formation and Dry Deposition at 2 Southern California Locations, Atmos. Environ. a-Gen, 26, 3279-3286, 1992.

Guenther, A., Karl, T., Harley, P., Wiedinmyer, C., Palmer, P. I., and Geron, C.: Estimates of global terrestrial isoprene emissions using MEGAN (Model of Emissions of Gases and Aerosols from Nature), Atmos. Chem. Phys., 6, 3181-3210, doi:10.5194/acp-63181-2006, 2006.

Hanson, A. D. and Roje, S.: One-carbon metabolism in higher plants, Annu. Rev. Plant Phys., 52, 119-137, 2001.

Harley, P., Greenberg, J., Niinemets, Ü., and Guenther, A.: Environmental controls over methanol emission from leaves, Biogeosciences, 4, 1083-1099, doi:10.5194/bg-4-1083-2007, 2007.

Harrington, R. F., Gertler, A. W., Grosjean, D., and Amar, P.: Formic-Acid and Acetic-Acid in the Western Sierra-Nevada, California, Atmos. Environ. a-Gen, 27, 1843-1849, 1993.

Huve, K., Christ, M. M., Kleist, E., Uerlings, R., Niinemets, U., Walter, A., and Wildt, J.: Simultaneous growth and emission measurements demonstrate an interactive control of methanol release by leaf expansion and stomata, J. Exp. Bot., 58, 1783-1793, doi:10.1093/Jxb/Erm038, 2007.

Jabrin, S., Ravanel, S., Gambonnet, B., Douce, R., and Rebeille, F.: One-carbon metabolism in plant, Regulation of tetrahydrofolate synthesis during germination and seedling development, Plant Physiology, 131, 1431-1439, doi:10.1104/Pp.016915, 2003.

Jardine, K., Harley, P., Karl, T., Guenther, A., Lerdau, M., and Mak, J. E.: Plant physiological and environmental controls over the exchange of acetaldehyde between forest canopies and the atmosphere, Biogeosciences, 5, 1559-1572, doi:10.5194/bg-5-15592008, 2008.
Jardine, K. J., Henderson, W. M., Huxman, T. E., and Abrell, L.: Dynamic Solution Injection: a new method for preparing pptvppbv standard atmospheres of volatile organic compounds, Atmos. Meas. Tech., 3, 1569-1576, doi:10.5194/amt-3-15692010, 2010a.

Jardine, K., Sommer, E., Saleska, S., Huxman, T., Harley, P., and Abrell, L.: Gas Phase Measurements of Pyruvic Acid and Its Volatile Metabolites, Environ. Sci. Technol., 44, 2454-2460, doi:10.1021/es903544p, 2010b.

Karl, T., Potosnak, M., Guenther, A., Clark, D., Walker, J., Herrick, J. D., and Geron, C.: Exchange processes of volatile organic compounds above a tropical rain forest: Implications for modeling tropospheric chemistry above dense vegetation, J. Geophys. Res.-Atmos., 109, D18306, doi:10.1029/2004JD004738, 2004.

Karl, T., Harley, P., Guenther, A., Rasmussen, R., Baker, B., Jardine, K., and Nemitz, E.: The bi-directional exchange of oxygenated VOCs between a loblolly pine (Pinus taeda) plantation and the atmosphere, Atmos. Chem. Phys., 5, 3015-3031, doi:10.5194/acp-5-3015-2005, 2005.

Karl, T., Guenther, A., Turnipseed, A., Tyndall, G., Artaxo, P., and Martin, S.: Rapid formation of isoprene photo-oxidation products observed in Amazonia, Atmos. Chem. Phys., 9, 7753-7767, doi:10.5194/acp-9-7753-2009, 2009.

Karl, T., Harley, P., Emmons, L., Thornton, B., Guenther, A., Basu, C., Turnipseed, A., and Jardine, K.: Efficient atmospheric cleansing of oxidized organic trace gases by vegetation, Science, 330, 816-819, doi:10.1126/science.1192534, 2010.

Keene, W. C., Galloway, J. N., and Holden, J. D.: Measurement of Weak Organic Acidity in Precipitation from Remote Areas of the World, J. Geophys. Res.-Oc. Atm., 88, 5122-5130, 1983.

Kesselmeier, J.: Exchange of short-chain oxygenated volatile organic compounds (VOCs) between plants and the atmosphere: A compilation of field and laboratory studies, J. Atmos. Chem., 39, 219-233, 2001.

Kesselmeier, J. and Staudt, M.: Biogenic volatile organic compounds (VOC): An overview on emission, physiology and ecology, J. Atmos. Chem., 33, 23-88, 1999.

Kesselmeier, J., Bode, K., Gerlach, C., and Jork, E. M.: Exchange of atmospheric formic and acetic acids with trees and crop plants under controlled chamber and purified air conditions, Atmos. Environ., 32, 1765-1775, 1998.

Kesselmeier, J., Kuhn, U., Rottenberger, S., Biesenthal, T., Wolf, A., Schebeske, G., Andreae, M. O., Ciccioli, P., Brancaleoni, E., Frattoni, M., Oliva, S. T., Botelho, M. L., Silva, C. M. A., and Tavares, T. M.: Concentrations and species composition of atmospheric volatile organic compounds (VOCs) as observed during the wet and dry season in Rondonia (Amazonia), J. Geophys. Res.-Atmos., 107, 8053, doi:10.1029/2000JD000267, 2002.

Kuhn, U., Rottenberger, S., Biesenthal, T., Ammann, C., Wolf, A., Schebeske, G., Oliva, S. T., Tavares, T. M., and Kesselmeier, J.: Exchange of short-chain monocarboxylic acids by vegetation at a remote tropical forest site in Amazonia, J. Geophys. Res.Atmos., 107, 8069, doi:10.1029/2000jd000303, 2002.

Lewis, S. L., Brando, P. M., Phillips, O. L., van der Heijden, G. M. F., and Nepstad, D.: The 2010 Amazon Drought, Science, 331, 554-554, doi:10.1126/science.1200807, 2011.

Liedvogel, B. and Stumpf, P. K.: Origin of Acetate in Spinach Leaf Cell, Plant Physiology, 69, 897-903, 1982.

Martin, S. T., Andreae, M. O., Althausen, D., Artaxo, P., Baars, H., 
Borrmann, S., Chen, Q., Farmer, D. K., Guenther, A., Gunthe, S. S., Jimenez, J. L., Karl, T., Longo, K., Manzi, A., Mller, T., Pauliquevis, T., Petters, M. D., Prenni, A. J., Pöschl, U., Rizzo, L. V., Schneider, J., Smith, J. N., Swietlicki, E., Tota, J., Wang, J., Wiedensohler, A., and Zorn, S. R.: An overview of the Amazonian Aerosol Characterization Experiment 2008 (AMAZE-08), Atmos. Chem. Phys., 10, 11415-11438, doi:10.5194/acp-1011415-2010, 2010

Niinemets, U. and Reichstein, M.: Controls on the emission of plant volatiles through stomata: Differential sensitivity of emission rates to stomatal closure explained, J. Geophys. Res.-Atmos., 108, 4208, doi:10.1029/2002jd002620, 2003.

Paulot, F., Wunch, D., Crounse, J. D., Toon, G. C., Millet, D. B., DeCarlo, P. F., Vigouroux, C., Deutscher, N. M., González Abad, G., Notholt, J., Warneke, T., Hannigan, J. W., Warneke, C., de Gouw, J. A., Dunlea, E. J., De Mazière, M., Griffith, D. W. T., Bernath, P., Jimenez, J. L., and Wennberg, P. O.: Importance of secondary sources in the atmospheric budgets of formic and acetic acids, Atmos. Chem. Phys., 11, 1989-2013, doi:10.5194/acp-11-1989-2011, 2011.

Pegoraro, E., Abrell, L., Van Haren, J., Barron-Gafford, G., Grieve, K. A., Malhi, Y., Murthy, R., and Lin, G. H.: The effect of elevated atmospheric $\mathrm{CO} 2$ and drought on sources and sinks of isoprene in a temperate and tropical rainforest mesocosm, Global Change Biology, 11, 1234-1246, doi:10.1111/j.13652486.2005.00986.x, 2005.

Sanhueza, E., Ferrer, Z., Romero, J., and Santana, M.: Hcho and Hcooh in Tropical Rains, Ambio, 20, 115-118, 1991.

Sanhueza, E., Santana, M., and Hermoso, M.: Gas-Phase and Aqueous-Phase Formic and Acetic-Acids at a Tropical Cloud Forest Site, Atmos Environ, 26, 1421-1426, 1992.

Seco, R., Penuelas, J., and Filella, I.: Short-chain oxygenated VOCs: Emission and uptake by plants and atmospheric sources, sinks, and concentrations, Atmos. Environ., 41, 2477-2499, doi:10.1016/j.atmosenv.2006.11.029, 2007.

Sommer, R., Sa, T. D. D., Vielhauer, K., de Araujo, A. C., Folster, H., and Vlek, P. L. G.: Transpiration and canopy conductance of secondary vegetation in the eastern Amazon, Agr. Forest Meteorol., 112, 103-121, 2002.
Talbot, R. W., Beecher, K. M., Harriss, R. C., and Cofer, W. R.: Atmospheric Geochemistry of Formic and Acetic-Acids at a MidLatitude Temperate Site, J. Geophys. Res.-Atmos., 93, 1638$1652,1988$.

Talbot, R. W., Andreae, M. O., Berresheim, H., Jacob, D. J., and Beecher, K. M.: Sources and sinks of formic, acetic, and pyruvic acids over central Amazonia. 2: Wet Season, J. Geophys. Res.Atmos., 95, 16799-16811, 1990.

Talbot, R. W., Mosher, B. W., Heikes, B. G., Jacob, D. J., Munger, J. W., Daube, B. C., Keene, W. C., Maben, J. R., and Artz, R. S.: Carboxylic-Acids in the Rural Continental Atmosphere over the Eastern United-States during the Shenandoah Cloud and Photochemistry Experiment, J. Geophys. Res.-Atmos., 100, 93359343, 1995.

Tani, A. and Hewitt, C. N.: Uptake of Aldehydes and Ketones at Typical Indoor Concentrations by Houseplants, Environmental Science \& Technology, 43, 8338-8343, doi:10.1021/Es9020316, 2009.

Vaïtilingom, M., Amato, P., Sancelme, M., Laj, P., Leriche, M., and Delort, A.-M.: Contribution of microbial activity to carbon chemistry in clouds, Appl. Environ. Microb., 76, citeulikearticle-id:6928263, 23-29, 2010.

Vourlitis, G. L., Nogueira, J. D., Lobo, F. D., Sendall, K. M., de Paulo, S. R., Dias, C. A. A., Pinto, O. B., and de Andrade, N. L. R.: Energy balance and canopy conductance of a tropical semideciduous forest of the southern Amazon Basin, Water Resour. Res., 44, W03412, doi:10.1029/2006wr005526, 2008.

Yu, S.: Role of organic acids (formic, acetic, pyruvic and oxalic) in the formation of cloud condensation nuclei (CCN): a review, Atmospheric Research, 53, 185-217, doi:10.1016/s01698095(00)00037-5, 2000.

Zhang, Y., Sun, K. H., Sandoval, F. J., Santiago, K., and Roje, S.: One-carbon metabolism in plants: characterization of a plastid serine hydroxymethyltransferase, Biochem. J., 430, 97-105, doi:10.1042/Bj20100566, 2010. 